\title{
Effects of Black Soldier Fly Carcass Flour on Feed Against Digestibility, Liver and Blood Image of Sangkuriang Catfish (Clarias gariepinus)
}

\author{
Muhammad Aidil Huda $^{1}$, Mas Tri Djoko Sunarno ${ }^{2}$, Moch Nurhudah ${ }^{1}$ \\ ${ }^{1}$ Jakarta Institute of Fisheries, Indonesia ${ }^{2}$ Research Institute for Freshwater Aquaculture and Fisheries \\ Extension, Bogor, Indonesia \\ Corresponding Email : Aidilhuda18@gmail.com
}

Received : 2 June 2020; Accepted: 29 June 2020

\begin{abstract}
Muhammad Aidil Huda, Mas Tri Djoko Sunarno, and Moch Nurhudah. 2020. Effects of Black Soldier Fly Carcass Flour on Feed Against Digestibility, Liver and Blood Image of Sangkuriang Catfish (Clarias gariepinus). Aquacultura Indonesiana, 21 (1): 42 - 48. The purpose of this study was to determine the effect of black soldier fly carcass flour on feed on digestibility, liver and blood features in Sangkuriang catfish (Clarias gariepinus). Sangkuriang catfish (Clarias gariepinus) used measuring $9-12 \mathrm{~cm}$ with a weight of $\pm 5.27 \mathrm{~g}$. The aquariums are used as many as 5 pieces measuring $100 \mathrm{~cm} \times 50 \mathrm{~cm} \times 51 \mathrm{~cm}$. The amount of sangkuriang catfish (Clarias gariepinus) stocked in the aquarium is 10 per aquarium and fed $6 \%$ of the total weight of all test fish. The treatments used are black soldier fly carcass flour and fish flour with a percentage of $0 \%, 25 \%, 50 \%, 75 \%$ and $100 \%$. The parameters tested were digestibility, liver picture and blood count of sangkuriang catfish (Clarias gariepinus). The results showed that the digestibility value of 50\% black soldier fly carcass flour (CF) treatment gave the best results. In addition, the liver picture in the $50 \% \mathrm{CF}$ treatment did not show any abnormalities in the liver of the Sangkuriang catfish (Clarias gariepinus). Amount of blood cells in 50\% CF treatment is in optimal condition. Based on these results indicate that the administration of Black Soldier fly carcass flour at CF 50\% treatment gives the best results on digestibility, liver picture and blood of Sangkuriang catfish (Clarias gariepinus), so that Black Soldier fly carcass flour can be used in feed formula.
\end{abstract}

Keywords: black soldier fly carcass flour, Digestion, liver picture, blood picture, sangkuriang catfish

\section{Introduction}

The quality of the black soldier fly carcass depends on the administration of the black soldier fly carcass to the biota especially in fish. For example, research Hariadi et al. (2014) on jambal catfish (Pangasius djambal) which stated that the balance between protein, fat and carbohydrate in the combination of feed $75 \%$ pellets and $25 \%$ black soldier fly carcass flour would encourage fish to utilize fat and carbohydrates as non-protein energy, while feed protein is used for growth. If the feed provided is experiencing a lack of fat and carbohydrates, then the protein in the feed will be used to meet the energy needs of fish for maintenance of living processes, so that the role of protein for growth is disrupted (Suhenda et al., 2005). Optimum feed for the cultivation of catfish jambal (Pangasius djambal) using Black Soldier fly carcass that is $79.00 \%-82.50 \%$ pellets and $17.50 \%-21 \%$. This is due to the ratio of energy and protein feed in a balanced amount between protein, fat and carbohydrates.

The use of other black soldier fly carcass flour can be seen in the research of Irfan and Abdul Manan (2013) on rainbow kuromoi fish, namely that the addition of the average weight of individuals to the rainbow kuromoi fish each treatment that was fed black soldier fly carcass flour showed a value that 
was not much different from individual weight is $10.42 \mathrm{~g}$ in treatment $\mathrm{A}$ and $10.53 \mathrm{~g}$ in treatment B. It can be concluded that the research did not experience any changes and for optimum value the black soldier fly carcass flour was relatively non-existent because each treatment had the same relative amount.

This study aims to determine the effect of adding black soldier fly carcass flour to feed on digestibility, liver features and blood cell counts of sangkuriang catfish (Clarias gariepinus).

\section{Materials and Methods}

\section{Test Fish}

The fish used in the study were Sangkuriang catfish (Clarias gariepinus) weighing $\pm 5.27 \mathrm{gr}$ and $9-12 \mathrm{~cm}$ long. The aquariums are used as many as 5 pieces with sizes $P=100 \mathrm{~cm}, L=50 \mathrm{~cm}, T=51 \mathrm{~cm}, T$ water $=30 \mathrm{~cm}$ and $\mathrm{V}=150 \mathrm{~L}$. Amount of fish in each aquarium is 10 . The feed used is a mixture of black soldier fly carcass flour with fish flour with a percentage of $0 \%$ (Control / 100\% fish flour), 25\% (75\% fish flour and $25 \%$ black soldier fly carcass flour), $50 \%$ (50\% fish flour and 50\% black soldier fly carcass flour), $75 \%$ (25\% fish flour and $75 \%$ black soldier fly carcass flour) and $100 \%$ (100\% black soldier fly carcass flour). The feed used is $6 \%$ of the body weight of sangkuriang catfish (Clarias gariepinus). Feed given to Sangkuriang catfish (Calrias gariepinus) is given 3 times a day at 7.am, $12 \mathrm{pm}$ and $4 \mathrm{pm}$.

\section{Digestibility Test}

The digestibility test is done by taking sangkuriang catfish (Clarias gariepinus) feces. Feces in sangkuriang catfish (Clarias gariepinus) are collected 3-4 hours after feeding. The process of collecting feces is done by first removing the remaining feed and feces, then given the treatment feed again. The process of feeding the Sangkuriang catfish (Clarias gariepinus) is carried out for 10-30 minutes after that if there is food left then discard it again.
After that, leave it for 3-4 hours so that the Sangkuriang catfish (Clarias gariepinus) emits faces. Intake of feces using tools such as hoses and small filters. Faces collection must be careful, because there is a mixture of feces with treatment feed. Faces taken and used should not exceed 4 hours due to the occurrence of decomposition of organic material in the faces of sangkuriang catfish (Clarias gariepinus) if it is taken too long.

To calculate the total digestibility and protein digestibility, we can use a formula (Watanabe, 1988) :

Total Digestibility $(\%)=100-[100 \times(\mathrm{a} / \mathrm{a})]$ Protein Digestibility $(\%)=100-\left[100 \times\left(\mathrm{a} / \mathrm{a}^{\prime}\right) \mathrm{x}\right.$ $\left.\left(\mathrm{b}^{\prime} / \mathrm{b}\right)\right]$

where: $\mathrm{a}=\% \mathrm{Cr}_{2} \mathrm{O}_{3}$ in feed; $\mathrm{a}^{\prime}=\% \mathrm{Cr}_{2} \mathrm{O}_{3}$ in feces

Faces $\quad b=\%$ Protein in feed; $b^{\prime}=\%$ Protein in

\section{Histology Test}

Histological examination is done by fixation by first inserting sangkuriang catfish (Clarias gariepinus) into 10\% formalin solution. After that dissect the body of the sangkuriang catfish (Clarias gariepinus) and take the internal organs in the form of the liver of the sangkuriang catfish (Clarias gariepinus) each treatment. After that the liver is cut again and refixed by cutting the liver with a size of $10 \times 10$ x $5 \mathrm{~mm}^{3}$ using a knife. After that, dehydration and paraffin filling by inserting a cassette in hisomodules fixation basket, then making the paraffin block. Furthermore, making preparations by cutting from the paraffin block using a knife which is then taken using wet cardboard and transferred to a container filled with warm water. After that the coloring process (Blaxhall and Daisley, 1973).

\section{Hematology Test}

Samples of sangkuriang catfish (Clarias gariepinus) were used to count the amount of blood cells as much as 5 from each treatment aquarium. The calculation of the amount of blood cells is done by taking blood of sangkuriang catfish (Clarias gariepinus) as much as 3 using a syringe. The blood sample is then put into a labeled testube. The calculation 
of red blood cells is done by sucking blood samples each treatment on the testube by using a pipette up to $0.5 \mathrm{~mm}$, then sipping the hayem solution up to a scale of $10 \mathrm{~mm}$ and homogenized. After that, throw the first drop in the solution and then put it into the haemacytometer and cover using a glass cover. The calculation is done by looking at 5 small boxes on the haemacytometer. The calculation of white blood cells is done by sucking blood samples at each treatment on the testube by using a pipette up to $0.5 \mathrm{~mm}$, then suction of the tuk's solution up to a scale of $10 \mathrm{~mm}$ and homogenized. After that, throw the first drop in the solution and then put it into the haemacytometer and cover using a glass cover. The calculation is done by looking at the top 5 on the haemacytometer (Blaxhall and Daisley, 1973).
Calculation of blood cells is carried out with the following formula (Hartika et al., 2014) :

$\Sigma$ Erythrocytes / Leukocytes $\left(\right.$ cell $\left./ \mathrm{mm}^{3}\right)=$ The erythrocyte / leukocyte cell count is calculated $=$ volume [mi ]

\section{Data Analysis}

Analysis of the data used is by using descriptive analysis in the form of an explanation of the parameters and the results obtained.

\section{Results}

The digestibility of nutrient ingredients for black soldier fly carcass flour is in table 1 .

Table 1. Digestibility of Black Soldier fly carcass nutrient ingredients

\begin{tabular}{cccccc}
\hline \multirow{2}{*}{ Test Parameters } & \multicolumn{5}{c}{ Black Soldier Fly Carcass Flour } \\
& $\mathbf{0 \%}$ & $\mathbf{2 5 \%}$ & $\mathbf{5 0 \%}$ & $\mathbf{7 5 \%}$ & $\mathbf{1 0 0 \%}$ \\
& $(\mathbf{C F}$ ) & $(\mathbf{C F}$ 25) & $(\mathbf{C F}$ 50) & $(\mathbf{C F ~ 7 5 )}$ & $(\mathbf{C F}$ 100) \\
\hline Total Digestibility (\%) & 82.48 & 85.18 & 83.71 & 81.53 & 81.87 \\
Protein Digestibility (\%) & 90.63 & 92.56 & 91.42 & 90.21 & 90.25 \\
\hline
\end{tabular}

From the test results showed that the total digestibility of black soldier fly carcass flour from the lowest to the highest was $81.87 \%-85.18 \%$ and the protein digestibility from the lowest to the highest was $90.21 \%$ $92.56 \%$. These results indicate that the total digestibility and digestibility of black soldier fly $(\mathrm{CF}) 25 \%$ protein and $50 \% \mathrm{CF}$ give the best results compared with $0 \% \mathrm{CF}$ (Control), $75 \%$ $\mathrm{CF}$ and $100 \% \mathrm{CF}$.

Histology research results of Sangkuriang catfish (Clarias gariepinus) treated with black soldier fly carcass flour treatment showed the presence of each treatment such as fat degeneration, inflammation infiltration, congestion and necrosis (Figure 1). 


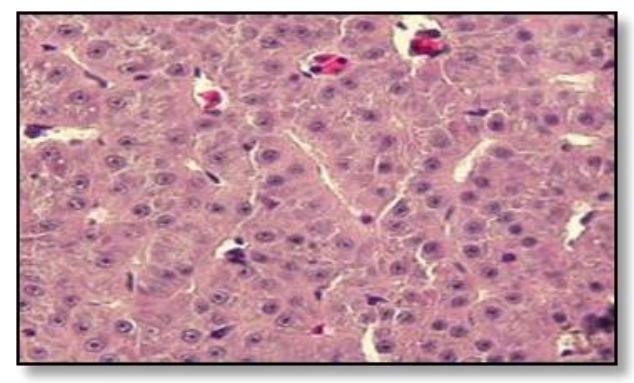

CF $50 \%$

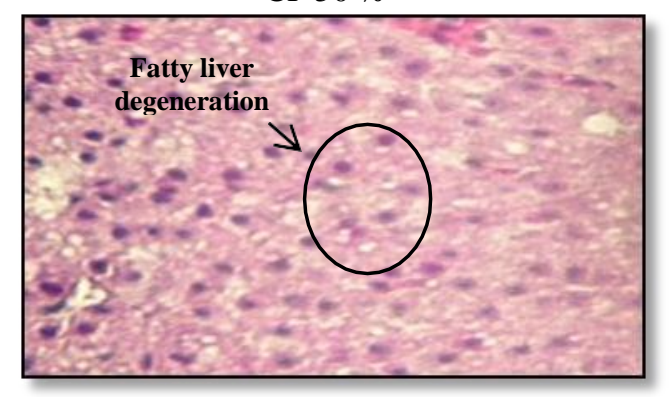

CF $75 \%$

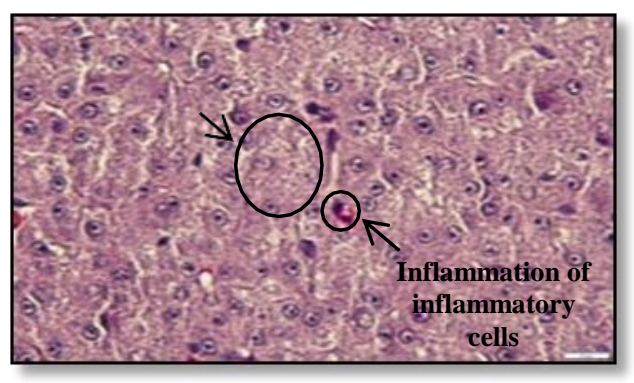

CF $25 \%$

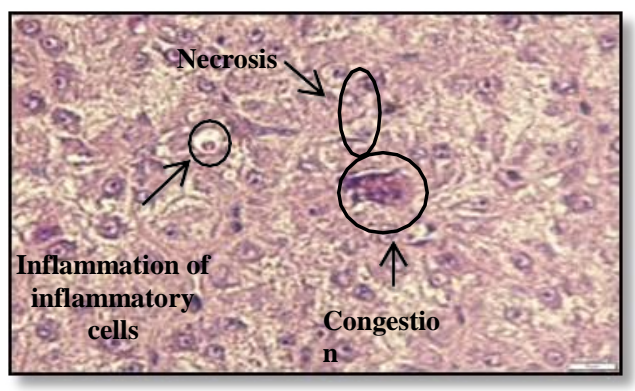

CF $100 \%$

Figure 1. A picture of the liver of a sangkuriang catfish (Clarias gariepinus)

Histology test results showed that $\mathrm{CF}$ $50 \%$ gave the best results compared to $\mathrm{CF} 0 \%$ (Control), CF 25\%, CF 75\%, and CF $100 \%$. The giving of $\mathrm{CF} 50 \%$ shows no symptoms in the liver of sangkuriang catfish (Clarias gariepinus), so that the $50 \% \mathrm{CF}$ treatment gives the best picture of the liver compared to the liver picture in other treatments.

The amount of red blood cells and white blood cells can be seen in table 2 .

Table 2. Amount of erythrocytes and leukocytes

\begin{tabular}{cccccc}
\hline \multirow{2}{*}{ Test Parameters } & \multicolumn{5}{c}{ Erythrocyte and Leukocyte Cells Analysis Results } \\
& $\mathbf{0 \%}$ & $\mathbf{2 5 \%}$ & $\mathbf{5 0 \%}$ & $\mathbf{7 5 \%}$ & $\mathbf{1 0 0 \%}$ \\
& $(\mathbf{C F}$ 0) & $(\mathbf{C F} \mathbf{2 5})$ & $(\mathbf{C F} \mathbf{5 0})$ & $(\mathbf{C F} 75)$ & $(\mathbf{C F} \mathbf{1 0 0})$ \\
\hline Erythrocytes $\left(\mathrm{Cell} / \mathrm{mm}^{3}\right)$ & $8.1 \times 10^{5}$ & $1.6 \times 10^{5}$ & $2.4 \times 10^{5}$ & $2.3 \times 10^{5}$ & $1.2 \times 10^{5}$ \\
Leukocytes $\left(\mathrm{Cell} / \mathrm{mm}^{3}\right)$ & 14700 & 4350 & 11450 & 16550 & 6650 \\
\hline
\end{tabular}

Based on these results indicate that the amount of erythrocytes and leukocytes in each treatment has a different amount depending on the treatment given to the sangkuriang catfish (Clarias gariepinus) examined. The amount of erythrocyte cells from the lowest to the highest is $1.2 \times 105$ cells $/ \mathrm{mm}^{3}$ to $8.1 \times 105$ cells / $\mathrm{mm}^{3}$, while the number of leukocyte cells from the lowest to the highest is 6650 cells $/ \mathrm{mm}^{3}$ to 14700 cells $/ \mathrm{mm}^{3}$. The highest amount of erythrocyte cells was found in $\mathrm{CF}$ as much as $50 \%$ and $\mathrm{CF} 75 \%$ compared to $\mathrm{CF} 25 \%$ and CF $100 \%$, while for CF $0 \%$ was control. The highest amount of leukocytes was found in $\mathrm{CF}$ $50 \%$ and $\mathrm{CF} 75 \%$ compared to $\mathrm{CF} 25 \%, \mathrm{CF}$ $100 \%$, and CF 0\% as Control.

\section{Discussion}

Nutrient digestibility is one of the first steps to find out the potential of raw materials used in feed. The digestibility value of feed ingredients and their contents is very necessary to be able to increase fish growth by calculating nutritional needs and metabolic yields that are removed (Zhou et al., 2004). Digestibility can show the amount of nutrient composition that is absorbed and used for the growth of fish metabolism (NRC, 2011). Black soldier fly carcass flour has a total digestibility value ranging from $81.53 \%$ to $85.15 \%$ and protein digestibility ranges from $90.21 \%$ to 
92.56\%. According to Mulyantini (2010) digestion must have a structure and function of crude fiber that is low in all nutrients so that it can be digested easily in sufficient quantities. Crude fiber has the property of absorbing water so that it triggers the rate of movement of digestibility to become smooth (Amarullah, 2004).

In the treatment of $25 \% \mathrm{CF}$ and $50 \%$ $\mathrm{CF}$ have a balanced crude fiber according to the percentage ratio in the feed formulation. Mawaddah et al. (2018) that black soldier carcass flies contain $6.98 \%$ crude fiber, while crude fiber content in fish flour according to Lestari et al. (2013) which is $3.54 \%$, with the content of crude fiber advancing the high total digestibility and nutrient digestibility in the $\mathrm{CF}$ treatment of $25 \%$ and $\mathrm{CF} 50 \%$, this is because the percentage of $\mathrm{CF}$ treatment is $25 \%$ and $\mathrm{CF}$ $50 \%$, this shows that there is fiber balance rough on the treatment. For the 0\% CF treatment (Control), $75 \% \mathrm{CF}$ and $100 \% \mathrm{CF}$ showed the lowest value, this is because the crude fiber in the treatment showed no balance in the feed formulation so as to produce total digestibility and lowest nutrient digestibility. Protein digestibility value in the research conducted is good and optimal, where this is supported by the statement of NRC (2011) that the good protein digestibility value of raw materials ranges from $75 \%$ to $95 \%$.

In the $\mathrm{CF} 50 \%$ treatment, there was no abnormality in the liver in Sangkuriang catfish (Clarias gariepinus). This indicates that the $\mathrm{CF}$ $50 \%$ treatment gives the best results in the liver of the sangkuriang catfish (Clarias gariepinus) in the absence of symptoms or abnormalities in the sangkuriang catfish (Clarias gariepinus). In this case the use of CF $50 \%$ can be used as a reference for treatment in the liver of the sangkuriang catfish (Clarias gariepinus).

In the $25 \% \mathrm{CF}$ treatment, $75 \% \mathrm{CF}$ and $100 \% \mathrm{CF}$ showed abnormalities in each liver treatment of sangkuriang catfish (Clarias gariepinus) ranging from inflammatory infiltration, fatty degeneration, congestion and necrosis. Damage to the liver of the Sangkuriang catfish (Clarias gariepinus) is caused by the addition of black soldier fly carcass flour to the Sangkuriang catfish feed (Clarias gariepinus) The addition of black soldier fly carcass flour has a different amount in each treatment. The difference in the composition of the treatment in the feed causes symptoms that trigger abnormalities and damage to the liver of the sangkuriang catfish (Clarias gariepinus). Changes in histological structure occur because most of the poisons in the liver of the Sangkuriang catfish that affect the liver in the Sangkuriang catfish (Clarias gariepinus) (Malik et al., 2016). The statement is supported by Hastuti and Subandiyono, (2011) which states that the occurrence of abnormalities in the liver is due to the fact that the liver is one of the organs that accumulates the most toxins in the body of the fish, so it experiences disruption of work on liver function and abnormalities in the liver. From the above symptoms it can be explained that the addition of black soldier fly carcass flour in inappropriate Sangkuriang catfish feed (Clarias gariepinus) will cause damage and abnormalities in the liver of the Sangkuriang catfish (Clarias gariepinus) catfish. The solution to prevent abnormalities in the liver of the sangkuriang catfish (Clarias gariepinus) is by knowing a balanced composition in the feed formulation such as CF 50\% treatment that has a balanced composition so that the composition does not cause symptoms and abnormalities in the liver of the sangkuriang catfish (Clarias gariepinus).

The lowest amount of erythrocytes was found in the CF treatment of $25 \%$ and $\mathrm{CF}$ $100 \%$. The decrease in the number of erythrocytes in sangkuriang catfish (Clarias gariepinus) is suspected because they experience symptoms of anemia. According to Wedemeyer and Yasutake (1997) that low total erythrocytes indicate that fish experience symptoms of anemia. In addition, the decrease in the amount of erythrocytes is due to the presence of exotoxins and endotoxins which cause inflammation or bleeding so that the number of erythrocytes decreases (Syamsir, 2008). The highest erythrocyte values were found in the treatment of $\mathrm{CF} 50 \%$ and $\mathrm{CF}$ $75 \%$. The increase in the amount of erythrocytes is thought to be due to a balanced composition in the addition of black soldier fly carcass flour to the feed, thereby increasing the number of erythrocytes in sangkuriang catfish (Clarias gariepinus). The highest amount of 
leukocytes is found in the treatment of $\mathrm{CF}$ $50 \%$ and $\mathrm{CF} 75 \%$. The high amount of leukocytes in the treatment shows that because there is resistance to foreign bodies in the body of the fish resulting in an immune response that is characterized by an increase in total leukocytes (Arindita, 2014). The increase in total leukocytes in fish is the body's defense response to antigens (Nurjannah et al., 2013). In addition, the increase in the number of leukocyte cells is thought to be due to the addition of black soldier fly carcass flour to feed where the addition makes the composition of feed on sangkuriang catfish (Clarias gariepinus) become balanced, so that the composition affects the number of leukocyte cells in sangkuriang catfish (Clarias gariepinus). The lowest number of leukocytes is in the treatment of CF $25 \%$ and CF $100 \%$. The decrease in the amount of leukocytes in sangkuriang catfish (Clarias gariepinus) is caused by leukocytes in the blood vessels going down to damaged tissues. In accordance with the opinion of Nuryati et al (2010) which states that the decrease in total leukocytes after infection is caused because these cells are active and out of the blood vessels into damaged tissue. In addition, the decrease in the number of leukocyte cells is thought to be due to the absence of composition of the addition of carcass black soldier fly flour to sangkuriang catfish feed (Clarias gariepinus), resulting in damaged tissue and decreased leukocyte cells in sangkuriang catfish (Clarias gariepinus). According to Irianto (2005) which states that the value of erythrocytes in telestoi fish has a range of 1.05-3.00x106 cells $/ \mathrm{mm}^{3}$, while according to Dapongtonung (2008) the amount of leukocytes in fish per $\mathrm{mm}^{3}$ of blood ranges from 20,000 - 150,000.

\section{Conclusion}

Based on total digestibility, protein digestibility, liver picture, and blood count, Black Soldier fly carcass flour in feed formulation can be used as raw material for Sangkuriang catfish feed (Clarias gariepinus) at a dose of $50 \%$ in feed

\section{Acknowledgement}

I thank my supervisor, Prof. Dr. Ir Mas Tri Djoko Sunarno, MS and Mr. Dr. Moch Nurhudah, M.Sc, who helped guide the completion of my research.

\section{References}

Amarullah, J,K. 2004. Broiler chicken nutrition. Cetakan ke-3. Lembaga Satu Gunungbudi. Bogor.

Arindita, C., Sarjito., \& Slamet, B,P. 2014. Effect of addition of Aloe vera powder in feed on the survival and blood profile of carp (Cyprinus carpio) infected with 'Aeromonas hydrophilla' bacteria

Blaxhall, P,C. \& Daisley, K,W. 1973. Routine haematological methods for use with dish blood. Journal Fish Biology, 5:577-581.

Dopongtonung, A. 2008. Image of blood of catfish (Clarias spp) originating from the LaladonBogor area. Fakultas Kedokteran Hewan. IPB.

Hastuti, S. \& Subandiyono. 2011. Haematological performance of African catfish (Clarias gariepinus) and water quality media in aquaculture systems with the application of biofiltration ponds. Jurnal Saintek Perikanan, 6(2), 1-5.

Hartika, R., Mustahal., and Achmad, N,P. 2014. Blood picture of tilapia (Oreochromis niloticus) with the addition of different prebiotic doses in the feed. Jurnal Perikanan dan Kelautan, 4(4), 259-267.

Irfan, M,S. and Abdul, M. 2013. Application of black soldier fly (Hermetia illucens) larvae as natural feed and artificial feed (Pellets) for rainbow kuromoi fish (Melanotaenia parva). Jurnal Ilmiah Perikanan dan Kelautan, 5(2).

Irianto, A. 2005. Teleostei fish pathology. Gajah Mada University. Press. Yogyakarta.

Lestari, S,F., Salnida, Y., and Zaenal, A. 2013. Effect of feed formulation made from fish meal, corn flour, fine bran and tofu dregs on the growth of tilapia (Orechromis niloticus). Jurnal Kelautan, 6(1), 36-46.

Mawaddah, S., Hermana, W., and Nahrowi. 2018. Effect of BSF (Hermetia illucens) larvae Deffated flour on production performance of quail laying (Coturnix coturnix japonica). Jurnal Ilmu Nutrisi dan Teknologi Pakan, 16(3), 47-51

Malik, F,M., Sri, H., \& Srjito. 2016. Effect of aquaponic biofilter system on blood profile, 
liver organ histology and survival in African catfish (Clarias gariepinus). Journal of Aquaculture Management and Technology, 5(1), 64-72

Mulyantini, N,G,A. 2010. Management of poultry. Cetakan Petama. Gajah Mada University Press. Yogyakarta.

NRC (National Research Cauncil). 2011. Nutrient requirements of fishes. Washington DC (US). National Acedemy of Science

Nurjannah, R.D.D., S.B. Prayitno., Sarjito dan A. M. Lusiastuti. 2013. Effect of Soursop (Annona muricata) Leaf Extract on Blood Profile and Survival of Carp (Cyprinus carpio) Infected by Aeromonas hydrophila Bacteria. J. Aquaculture Mangement and Technology., 2 (4): 72-83.

Nuryati, S., N.A. Maswan., Alimuddin., Sukenda., K. Sumantadinata., F.H. Pasaribu., R.D. Soejoedono dan A. Santika. 2010. Overview of Carp Blood after Vaccination with DNA Vaccine and Tested with Koi Herpes Virus. J. Akuakultur Indonesia., 9 (1): 9-15.

Watanabe, T. 1988. Fish nutrition and mariculture. Tokyo (JP) : Departement of Aquatic Bioscience. Tokyo University. JICA.

Wedemeyer, G,A., and Yasutake, W,T. 1997. Clinical methods for the assessment of the effect environmental stress on fish health. Technical Papers of the U.S Fish and Wildlife Service, U.S department of the Interior, 89: 1-18.

Zhou, Q,C., Bei, P,T., Kang, S,M., and Yong, J,L. 2004. Apparent digestibility of selected feed ingredients for juvenile cobia Rachycenron canadum. Aquaculture, 241: 441-451 